\title{
Penyuluhan tentang Bahaya Merokok pada Siswa SMAN 2
}

\author{
Iceu Amira DA, Hendrawati, Sukma Senjaya \\ Fakultas Keperawatan, Universitas Padjadjaran \\ Email:iceuamiraa@gmail.com
}

\begin{abstract}
Abstrak
Perilaku merokok menjadi permasalahan, baik secara lingkungan maupun individu. Artinya perilaku merokok selain disebabkan faktor dari dalam diri juga disebabkan oleh lingkungan, salah satunya adalah teman sebaya yang pada tahap awal mempengaruhi untuk melakukan merokok (46\%), seorang anggota keluarga bukan orang tua (23\%), dan orang tua (14\%). Tujuan kegiatan ini agar siswa memahami upaya pencegahan bahaya merokok, mensosialisasikan kepada sekolah dan masyarakat. Metode dari kegiatan ini untuk memberikan penyuluhan kesehatan tentang bahaya merokok, sasarannya semua siswa SMAN 2 Kabupaten Garut. Kegiatan ini dimulai dengan membuat perencanaan, pelaksanaan, evaluasi, hingga penyusunan laporan. Hasil kegiatan berdasarkan pengukuran pengetahuan melalui pre dan post test. Hasil pre test $41 \%$ siswa tidak mengetahui mengenai bahaya merokok, $43 \%$ tahu sebagian, dan $12 \%$ memahaminya. Dari 15 pertanyaan jawaban yang salah, paling banyak pertanyaan berkaitan dengan bahaya merokok dan penyakit /dampak dari perokok aktif serta perokok pasif. Setelah materi di sampaikan kemudian melaksanakan post test bertujuan untuk mengetahui sejauh mana perubahan pengetahuannya siswa-siswi setelah mendapatkan materi, diikuti 159 siswa/ peserta ,dengan hasil sebagai berikut: nilai 95 sebanyak 3 orang, nilai 90 sebanyak 13 orang, dan nilai 85 sebanyak 22 orang, nilai 82 sebanyak 25 orang, nilai 80 sebanyak 22 orang, nilai 77 sebanyak 25 orang, nilai 75 sebanyak 18 orang, nilai 70 sebanyak 14 orang dan nilai 60 sebanyak 17 orang. Dilihat dari hasil post test ,tujuan tercapai, hampir $90 \%$ siswa / siswi SMA Negeri 2 kabupaten Garut mengetahui mengenai bahaya merokok, hasil dari pre test ke post test ada kenaikan sebesar $47 \%$.
\end{abstract}

Kata kunci: Bahaya Merokok, penyuluhan, siswa.

\begin{abstract}
Smoking behavior is an environmental and individual problem. This means that smoking behavior is caused not only by the individual but also caused by the environment. Studies on smoking have showed that smoking in the early stages was carried out with friends (46\%), with a family member (23\%), and with parents $(14 \%)$. The purpose of this counseling is to let the students know about the efforts to prevent the dangers of smoking and to socialize the case to schools and the community. The method of this activity was to provide health education about the dangers of smoking to all students of SMAN 2 Garut Regency. This activity began with planning, implementing, evaluating, and preparing reports. The results of the activity were based on the participant's knowledge gained from pre and post-test. Pre-test results showed that $41 \%$ of the students did not know about the dangers of smoking, another $43 \%$ of students knew partially, and the other $12 \%$ of the students understood it. Of the 15 questions, the most wrong answers are given to the questions related to the danger and diseaselthe impact of active smokers and passive smokers. After the materials were given, then the researcher carried out a post-test which has purpose to determine the extent of changes in knowledge of students after getting the materials/ The post-test was taken by 159 students and resulted in the following results: the students who scored 95 were 3 students, 90 were 13 students, 85 were 22 students, 82 were 25 students, 80 were 22 students, 77 were 25 students, 75 were 18 students, 70 were 14 students and 60 were 17 students. Based on the post-test results, it can be concluded that the goal was achieved. Almost $90 \%$ of the students of SMAN 2 Garut knew the dangers of smoking and the increase from pre-test to post-test was $47 \%$.
\end{abstract}

Keywords: Counseling, Dangers of Smoking, Students. 


\section{Pendahuluan}

Perilaku merokok merupakan masalah lingkungan dan individu. Artinya perilaku merokok selain disebabkan faktor dari dalam diri juga disebabkan oleh lingkungan. Disebutkan juga bahwa merokok pada tahap awal dilakukan dengan teman sebayanya (46\%), seorang anggota keluarga bukan orang tua (23\%), dan orang tua (14\%). Hal ini yang mendukung hasil penelitian Komasari dan Helmi yang menyebutkan bahwa ada 3 faktor penyebab merokok pada perempuan yaitu kepuasan psikologis, sikap permisif orang tua dengan periaku merokok, dan pengaruh teman sebaya (Komasari \& Helmi, 2000).

Perilaku merokok penduduk 15 tahun keatas masih belum terjadi penurunan dari 2007 ke 2013, cenderung meningkat dari 34,2 persen tahun 2007 menjadi 36,3 persen tahun 2013. 64,9 persen laki-laki dan 2,1 persen perempuan masih menghisap rokok tahun 2013. Ditemukan 1,4 persen perokok umur 10-14 tahun, 9,9 persen perokok pada kelompok tidak bekerja, dan 32,3 persen pada kelompok kuintil indeks kepemilikan terendah. Sedangkan rerata jumlah batang rokok yang dihisap adalah sekitar 12,3 batang, bervariasi dari yang terendah 10 batang di DI Yogyakarta dan tertinggi di Bangka Belitung (18,3 batang).(Riskesdas, 2013).

Konsumsi rokok dan tembakau merupakan salah satu faktor resiko utama terjadinya berbagai penyakit. Menurut WHO rokok adalah pembunuh yang akrab di sekeliling kita, karena setiap 6 detik, satu orang meninggal akibat merokok. (Ahmad \& Kiay, 2017). Ada beberapa alasan yang dikemukakan oleh para ahli untuk menjawab mengapa seseorang merokok. Setiap individu mempunyai kebiasaan merokok yang berbeda dan biasanya disesuaikan dengan tujuan mereka merokok. Pendapat tersebut diperkuat dangan pernyataan bahwa seseorang merokok karena factor sosio cultural seperti kebiasaan budaya, kelas social, gengsi, dan tingkat pendidikan (Rahmadi, Lestari, \& Yenita, 2013)

Saat ini merokok merupakan kebiasaan yang umum dilakukan oleh semua orang termasuk perempuan. Perokok biasanya berasal dari berbagai kalangan dan umur, hal ini disebabkan karena rokok dapat dengan mudah diperoleh dimana saja.

Sekarang ini kurang lebih $80 \%$ perokok hidup di negara berkembang dan angka ini sudah tumbuh pesat dalam beberapa dekade saja. Diperkirakan pada tahun 2020, $70 \%$ dari seluruh kematian yang disebabkan rokok akan terjadi di negara-negara 
berkembang, naik dari tingkatan sekarang ini yaitu 50\%. Ini berarti dalam beberapa dekade yang akan datang negara-negara berkembang akan berhadapan dengan biaya yang semakin tinggi untuk membiayai perawatan kesehatan para perokok dan hilangnya produktifitas.

Semua orang mengetahui bahaya merokok bagi kesehatan. Bahaya merokok bagi kesehatan bisa berdampak dalam bentuk fisik, psikologis, sosial maupun fisiologis (ketergantungan). Tembakau yang ada pada rokok adalah produk konsumen yang secara unik berbahaya dan mematikan. Penggunaan tembakau tidak hanya menyakiti mereka yang mengonsumsinya tapi juga orang-orang lain yang terpapar asapnya (Vidya Purnama Sari Lubis 1,R. Kintoko Rochadi, 2012).

Menurut Crofton dan Simpson (2002), dalam Christina Imelda.S, Juanita, \& Rusmalawaty $^{2}$, (2012) 34 penelitian mengenai kanker paru menunjukkan suatu kombinasi peningkatan risiko 24\% lebih tinggi kejadian kanker paru pada mereka yang terpajan asap rokok dalam rumah. Karena adanya risiko ini, berbagai upaya dilakukan oleh banyak Negara untuk melindungi mereka yang bukan perokok dari asap rokok. Melalui perundangan dan persuasi, makin banyak alat transportasi, tempat-tempat umum, tempat kerja, dan rumah menjadi kawasan tanpa asap rokok.

Sekitar 65,6 juta wanita dan 43 juta anak-anak di Indonesia terpapar asap rokok atau menjadi perokok pasif. Mereka pun rentan terkena berbagai penyakit seperti bronkitis, kanker usus, kanker hati, stroke, dan berbagai penyakit akibat asap rokok. Soewarno Kosen mengungkapkan bahwa banyak warga Indonesia terpapar asap rokok karena 91,8\% perokok merokok di rumah (Zulkifli, 2010). dalam Sukatno, (2014)

Ada beberapa cara menghindari kebiasaan merokok. Pada dasarnya semua perokok tahu, bahwa merokok merupakan sebuah tingkah laku yang merugikan kesehatan. Hanya saja kebiasaan tersebut susah dihilangkan. Merokok merupakan salah satu aktivitas yang dipengaruhi oleh kecanduan zat-zat yang ada dalam rokok.

\section{Metode}

Pengabdian kepada masyarakat ini akan dilaksanakan kepada semua siswa SMAN 2 Kabupaten Garut, dengan menekankan pada partisipasi siswa mulai kelas 1 sampai kelas 3, di bimbing oleh guru (BP). Sebelum kegiatan pengabdian dilaksanakan terlebih dahulu melakukan silaturahmi dengan kepala sekolah beserta guru lainnya 
dan tata usaha, untuk menjelaskan alasan kunjungan ke sekolah, Pada tahap ini juga dilakukan jalinan kerjasama dan menentukan jadwal kegiatan ,pengabdian.untuk menyusun berbagai hal yang akan disampaikan pada saat kegiatan pengabdian Adapun kegiatannya yaitu penyusunan materi, pembagian tugas tim pengabdian dan survei ke lokasi pengabdian. Tim pelaksana kegiatan pengabdian pada masyarakat adalah dosen Fakultas Keperawatan Universitas Padjadjaran sebanyak 3 orang. Peserta pengabdian adalah semua siswa SMAN 2 Kabupaten Garut dari kelas 1 sampai kelas 3.

Kegiatan penyuluhan dilaksanakan dengan tujuan, untuk memberi bekal pengetahuan kepada siswa tentang bahaya merokok.. Dalam kegiatan penyuluhan membahas tentang pengertian merokok, kandungan rokok, karakter perokok, akibat merokok dan bahaya ketagihan merokok. Kegiatan Pengabdian kepada masarakat dilaksanakan pada hari jumat tanggal 27 April 2018, dengan pembukaan oleh bagian kesiswaan.

Setelah melakukan pre test dimulai dengan melakukan apersepsi yaitu untuk mengetahui sampai sejauh mana pengetahuan siswa tentang bahaya merokok, hasilnya siswa hanya mengetahui sebagian dari bahaya merokok, siswa memperhatikan jalannya penyuluhan selanjutnya diadakan tanya jawab tentang materi yang diberikan, siswa dengan antusiasnya menjawab semua pertanyaan yang terdiri dari dan saling berbagi pengalamannya tentang bahaya merokok, ada 5 siswa yang menjawab pertanyaan, tentang pengertian merokok, kandungan rokok, karakter perokok, akibat merokok, bahaya ketagihan merokok, setelah selesai penyuluhan menyimpulkan hasil dari penyuluhan

\section{Hasil}

Kegiatan Pengabdian kepada masarakat dilaksanakan pada hari jumat tanggal 27 April 2018, dengan pembukaan oleh bagian kesiswaan. Peserta berjumlah 241 orang yaitu siswa siswi SMAN 2 Kabupaten Garut ,yang suka merokok dengan diberikan kuesioner terlebih dahulu untuk mengetahui perokok dan bukan perokok. Peserta mengikuti penyuluhan dengan antusias. Kegiatan ini diawali dengan pengukuran pengetahuan dengan pre dan post test. Sebagai berikut : 
Tabel 1 hasil pre test dan post test Bahaya merokok

\begin{tabular}{lllll}
\hline No & Test & $\begin{array}{l}\text { Tidak } \\
\text { mengetahui }\end{array}$ & $\begin{array}{l}\text { Tahu } \\
\text { sebagian }\end{array}$ & memahami \\
\hline 1 & Pre test & $41 \%$ & $43 \%$ & $12 \%$ \\
\hline 2 & Post test & $3 \%$ & $10 \%$ & $87 \%$ \\
\hline
\end{tabular}

\section{Pembahasan}

Dari 15 pertanyaan banyak jawaban yang salah adalah pertanyaan yang berkaitan dengan bahaya dan penyakit /dampak dari perokok aktif dan perokok pasif, tetapi setelah materi di sampaikan ,kemudian dilaksanakan post test dengan tujuan untuk mengetahui sejauh mana perubahan pengetahuannya siswa-siswi , dan diikuti 159 siswa/ peserta dengan hasil ,tujuan tercapai yaitu hampir $90 \%$ siswa dan siswi SMA Negeri 2 kabupaten Garut, mengetahui mengenai bahaya merokok, sehingga ada kenaikan dari hasil pre test sebesar $47 \%$.

\section{Simpulan}

Setelah dilakukan penyuluhan tentang bahaya merokok, siswa dapat memahami bahaya merokok bagi kesehatan, disarankan kepada orangtua agar mengawasi anaknya dan membimbing agar terhindar dari kebiasaan merokok.

\section{Daftar Pustaka}

Ahmad, T., \& Kiay, I. P. D. (2017). Description of Smoking Behavior In Pulmonary Tuberculosis Patients At The Public Health Center Laatula Jaya 2014-2015, 4(2), $41-51$.

Christina Imelda.S, , Juanita, \& Rusmalawaty. (2012). Pengaruh pengetahuan dan sikap guru dan siswa tentang rokok dan kebijakan kawasan tanpa rokok terhadap partisipasi dalam penerapan kawasan tanpa rokok di SMP Negeri 1 Kota Medan tahun 2012. Jurnal Kebijakan, Promosi Kesehatan Dan Biostatistika, 1(1), 1-9.

Komasari, D., \& Helmi, A. F. (2000). Faktor-Faktor Penyebab Perilaku Merokok Pada Remaja. Jurnal Psikologi.

Rahmadi, A., Lestari, Y., \& Yenita, Y. (2013). Hubungan Pengetahuan dan Sikap Terhadap Rokok Dengan Kebiasaan Merokok Siswa SMP di Kota Padang. Jurnal Kesehatan Andalas, 2(1), 25-28.

Riskesdas. (2013). Riset Kesehatan Dasar Kementerian RI. Proceedings, Annual Meeting - Air Pollution Control Association (Vol. 6). https://doi.org/1 Desember 2013

Sukatno. (2014). Pelaksanaan Layanan Informasi Untuk Mengurangi Kebiasaan Siswa yang Merokok di SMK Negeri 1 Padangsidimpuan. 